\title{
The Shelf life Estimation of Cold Sterilized Coconut Water
}

\author{
DOI: $10.18196 /$ pt.2017.072.62-69
}

\author{
Sari Intan Kailaku ${ }^{1 *}$, Budi Setiawan ${ }^{2}$, Ahmad Sulaeman $^{2}$, Risfaheri $^{1}$ \\ ${ }^{1}$ Indonesian Center for Agricultural Postharvest Research and Development, Jl. Tentara Pelajar 12 Bogor 16114, Indonesia \\ ${ }^{2}$ Community Nutrition Department, Bogor Agricultural University, Jl. Raya Darmaga,Bogor 16680, Indonesia \\ *Corresponding author, email: sari.kaylaku@gmail.com
}

\begin{abstract}
Coconut water is well known due to its nutrient contents. Unfortunately, the properties such as flavor, aroma, and taste is easily altered, soon after it is extracted from the fruit by splitting the fruit in two and collecting the water in a clean container. The shelf-life of coconut water drink can be improved by eliminating the enzyme that causes the degredation of the quality, i.e. polyphenol oxidase and peroxidase enzyme. Heat treatment such as pasteurization and Ultra Heat Treatment may inhibit the growth of these enzymes although resulted in the loss of coconut water unique and desirable properties. Ultrafiltration membrane and ultraviolet are two potential cold-sterilization methods. The objective of this research was to estimate the shelf-life of coconut water after ultrafiltration membrane and ultraviolet sterilization. Cold-sterilized coconut water was stored at three temperatures, i.e. 8,13 and $25^{\circ} \mathrm{C}$, using polyethylene bottles in individual sizes $(250 \mathrm{ml})$. The shelf-life was estimated using Accelerated Storage Study method with Arrhenius equation. pH and total sugar contents were measured as critical parameters, and total plate count was also observed. This research concludee that the shelf-life of coconut water which cold sterilized without any food additives was etimated to be 15 days at $25^{\circ} \mathrm{C}$. Keywords: Coconut water, Shelf-life estimation, Storage, Ultrafiltration membrane, Ultraviolet
\end{abstract}

\begin{abstract}
ABSTRAK
Air kelapa terkenal akan berbagai kandungan zat gizinya. Namun, aroma dan rasa dari air kelapa mudah berubah, segera setelah dikeluarkan dari buahnya (dengan membelah dua buah dan menampung air dalam wadah bersih). Umur simpan minuman air kelapa dapat ditingkatkan dengan menghilangkan enzim penyebab perubahan kualitas, yaitu enzim polifenol oksidase dan peroksidase. Perlakuan panas seperti pasteurisasi dan Ultra Heat Treatment dapat menghambat pertumbuhan enzim-enzim ini meskipun akan menyebabkan hilangnya karakteristik air kelapa yang unik dan disukai. Membran ultrafiltrasi dan sinar ultraviolet adalah dua metode sterilisasi dingin yang potensial. Tujuan penelitian ini adalah untuk menduga umur simpan air kelapa setelah sterilisasi menggunakan membran ultrafiltrasi dan sinar ultraviolet. Air kelapa yang telah disterilisasi dingin kemudian disimpan pada tiga suhu, yaitu 8,13 dan $25{ }^{\circ} \mathrm{C}$, menggunakan botol polietilen berukuran individual (250 ml). Pendugaan umur simpan dilakukan menggunakan metode Accelerated Storage Study yaitu dengan persamaan Arrhenius. Nilai pH dan kadar gula total diukur sebagai parameter kritis, dan total plate count juga diamati. Sebagai kesimpulan, umur simpan air kelapa yang telah disterilisasi dingin dengan tanpa penambahan bahan tambahan apapun diduga 15 hari pada suhu $25^{\circ} \mathrm{C}$.

Kata kunci: Air kelapa, Pendugaan umur simpan, Penyimpanan, Membran ultrafiltrasi, Ultraviolet
\end{abstract}

\section{INTRODUCTION}

Coconut is well known due to its many benefits from every part of the coconut. Technology development had resulted in various products from coconut, giving considerable added values. One of underutilized coconut parts is coconut water. Most of the coconut water is unused and discarded into the environment, especially those from copra and coconut oil industry. The main obstacle to the development of coconut water product is its easily altered properties. Immediately after contact with air, coconut water will lose almost all its unique organoleptic properties and starts fermenting. Thus, in just a few hours after extracted from the fruit (usually by splitting the fruit in two), coconut water will turn turbid, yellowish, sour, and bad aroma. These alterations were caused by the existence of oxidase enzymes, i.e. polyphenol oxidase and peroxidase (Duarte et al., 2002; Magalhaes et al., 2005) and the microbe contamination (Magalhaes et al., 2005).

The shelf-life of coconut water isotonic drink can be improved by ensuring the elimination of the causes of its quality degradation. There are some methods can be conducted to preserve coconut water. Most of the commercial production of coconut water based drinks use pasteurization 
and Ultra-High-Temperature technology. However, the processing using high temperature may cause the loss of nutritional value and the unique aroma and flavor of coconut water (Haynes et al., 2004).

Coconut water processing without high temperature had been introduced by FAO (2000), using microfiltration membrane. This process was then further developed by Kailaku et al. (2006) where after microfiltration, ultrafiltration membrane was used. Ultrafiltration is a separation process using a membrane, working in the pressure difference principal. Ultrafiltration and pasteurization process had been shown to have the same effectiveness in reducing the enzymes activities in coconut water (Nakano et al., 2011). However, there was still doubt in its effectivity in reducing microorganism activities. Ultraviolet technology is a becoming more commonly used in purification and sterilization various products such as water, fruit juices, etc. (Falguera et al., 2011).

The combination of ultrafiltration and ultraviolet technology may increase the inactivation of microorganisms responsible for degrading the quality of coconut water. Both technologies need low energy intake and were expected to be able to maintain the nutritional and chemical composition along with the organoleptic properties of coconut water. The objective of this research was to estimate the shelf-life of coconut water after processing with ultrafiltration membrane and ultraviolet sterilization.

\section{MATERIAL AND METHODS}

The production, characterization, and analysis of coconut water drink were conducted at Research and Development Laboratory, Indonesian Center for Agricultural Postharvest Research and Development, Bogor, Indonesia. The flow chart of coconut water drink production using ultrafiltration membrane and ultraviolet sterilization was presented in Figure 1.

The development of coconut water drink did not include formulation stage. The material used in this study was only fresh coconut water, without any addition of food additives, in order to obtain the influence information of ultrafiltration and ultraviolet processing without factors of other ingredients or treatments. The coconut was Genjah variety and was collected at the age of 8-9 months from local community plantation in Bogor, Indonesia.

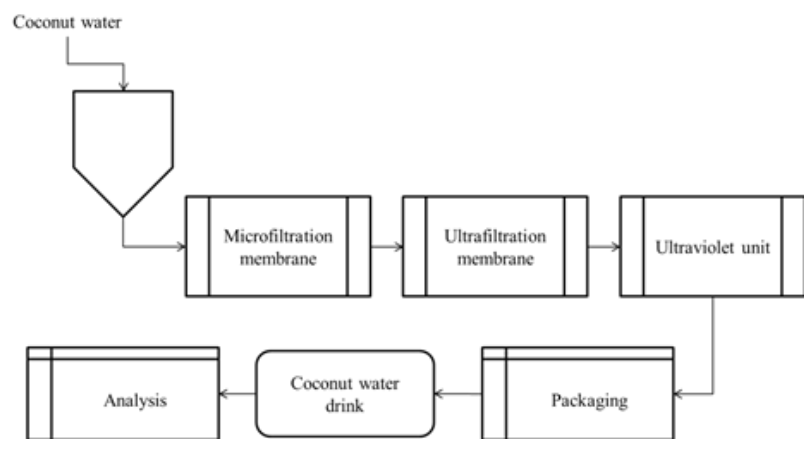

Figure 1. Flow chart of the cold sterilization of coconut water

Fresh coconut water was immediately coldsterilized by filtering through microfiltration (1000 $\mathrm{nm}$ pore size diameter) and ultrafiltration (50 $\mathrm{nm}$ pore size diameter) membranes followed by passing through the ultraviolet tube. The ultrafiltration membrane was operated at maximum pressure of 3 bar. UV tube dimension was 64 x $340 \mathrm{~mm}$ in diameter and length, respectively. The flow rate of the product through the tube was 1 litre/sec. The sterilized coconut water flowed from UV tube directly into a container through a rubber tube.

The product were analyzed for its physicochemical properties and nutritional composition, i.e. pH (Indonesian National Standard 
SNI 06-6989.11-2004), clarity (Spectrophotometer), colour (Chromameter), total soluble solid (AOAC, 2005), total sugar content (Sulaeman et al., 1995 in Riyana, 2008), sucrose, fructose and glucose content (Indonesian National Standard SNI 01-2892-1992), vitamin B1 and B6 content (Hidayati, 1992), vitamin C (High Performance Liquid Chromatography) and $\mathrm{K}, \mathrm{Na}$ and $\mathrm{Mg}$ content (APHA, 1998 in Roji, 2006).

Critical parameters ( $\mathrm{pH}$ and total sugar content) were observed nine times in 19 days. Coconut water drink was stored in temperature controlled room using three different temperatures, i.e. 8,13 and $25^{\circ} \mathrm{C}$. Samples were bottled in clear polyethylene plastic bottle in individual size $(250 \mathrm{ml})$.

Data obtained from analysis where processed based on Arrhenius method. The calculation of shelf-life was done using equation 1 (Sukasih et. al. 2007).

$$
t s=[\ln (N o-N t)] / K_{T}
$$

where: ts $=$ duration of storage

$$
\begin{aligned}
\mathrm{No}_{\mathrm{O}}= & \text { value of quality parameter on } \mathrm{t}_{0} \\
& \text { (the beginning of storage) } \\
\mathrm{Nt}= & \text { value of quality parameter after } \mathrm{t} \\
& \text { duration of (critical limit) } \\
\mathrm{K}_{\mathrm{T}}= & \text { value of } \mathrm{K} \text { in storage temperature } \mathrm{T}
\end{aligned}
$$

\section{RESULTS AND DISCUSSION}

Characterization of cold-sterilized coconut water

The composition of nutrition content and physicochemical properties of cold-sterilized coconut water as shown in Table 1. The appearance of fresh coconut water and cold-sterilized coconut water as seen in Figure 2. Kailaku et al., 2016 reported that the differentiation analysis of cold-sterilized coconut water and fresh coconut water showed that most of the coconut water nutritional composition was not different with that of fresh coconut water. The difference was only observed in total sugar content, although sucrose, fructose, and glucose content were not significantly different. The physical characteristics were also mostly unaffected by the cold-sterilization, except for the clarity and color parameters $\left(L^{*}\right.$ dan $\left.b^{*}\right)$. The theses stated that an amount of sugar content in coconut water may be filtered by ultrafiltration membrane, causing the small decrease of total sugar content $(p=0.049)$.

Table 1. The characteristics of cold-sterilized coconut water compared with fresh coconut water

\begin{tabular}{lccc}
\hline \multicolumn{1}{c}{ Characteristics } & $\begin{array}{c}\text { Fresh Coconut } \\
\text { Water }\end{array}$ & $\begin{array}{c}\text { Cold-sterilized } \\
\text { Coconut Water }\end{array}$ & p-value \\
\hline pH & 5.60 & 5.40 & 0.126 \\
Total sugar (\%) & 6.13 & 6.06 & $0.049^{*}$ \\
Sucrose (\%) & 0.64 & 0.62 & 0.758 \\
Fructose (\%) & 2.71 & 2.63 & 0.537 \\
Glucose (\%) & 2.72 & 2.70 & 0.500 \\
Potassium (mg/kg) & 1840.54 & 1736.46 & 0.272 \\
Sodium (mg/kg) & 20.73 & 14.17 & 0.174 \\
Magnesium (mg/kg) & 86.54 & 75.30 & 0.232 \\
Vitamin B1 (mg/100ml) & 11.97 & 11.85 & 0.053 \\
Vitamin B6 (mg/100ml) & 0.033 & 0.029 & 0.455 \\
Clarity (\% to water) & 97.4 & 89.5 & $0.001^{*}$ \\
Colour & & & \\
L & 101.78 & 97.05 & 0.000 \\
a & -0.24 & -0.18 & 0.390 \\
b & -0.06 & 0.58 & $0.002^{*}$ \\
Total plate count (cfu/ml) & $1.86 \times 102$ & $1.08 \times 101$ & na \\
\hline
\end{tabular}

*significantly different at alpha $=0.05$, na $=$ not available

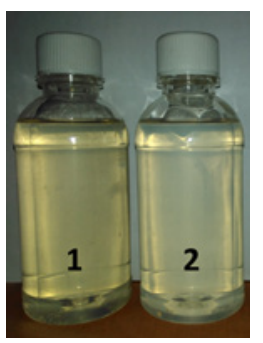

Figure 2. The appearance of fresh coconut water (1) and cold-sterilized coconut water (2)

\section{Shelf-life estimation}

The estimation of shelf-life is very important in commercialization of food product, especially 
a newly developed food product. Food shelf-life is a period of time after production where a product is able to maintain acceptability, both in sensory and nutritional, and safe for consumption (Ahrne et al. 1996). The shelf-life of a product can be estimated using various methods, one of which is using kinetics model such as Arrhenius model (Maria and Peleg 2007).

Arrhenius method uses acceleration (Accelerated Storage Study/ASS) and implements reaction kinetics study with the aid of Arrhenius equation. The principal is to store a food product at a certain temperature, in order to cause quality deterioration of its critical parameters due to the influence of heat. This method allows the research on storage to use three different temperatures to predict the shelf-life of different storage conditions (Hough et al. 2006).

The first step of ASS is the determination of critical parameters. Critical parameters used in this study were $\mathrm{pH}$ and total sugar content. These parameters were selected based on the consideration that the $\mathrm{pH}$ of coconut water is easily altered during storage, while total sugar content is one of the important sensory parameters that determine the acceptability of coconut water. The changes of $\mathrm{pH}$ value and total sugar content of cold-sterilized coconut water are presented in Figure 3 and Figure 4.

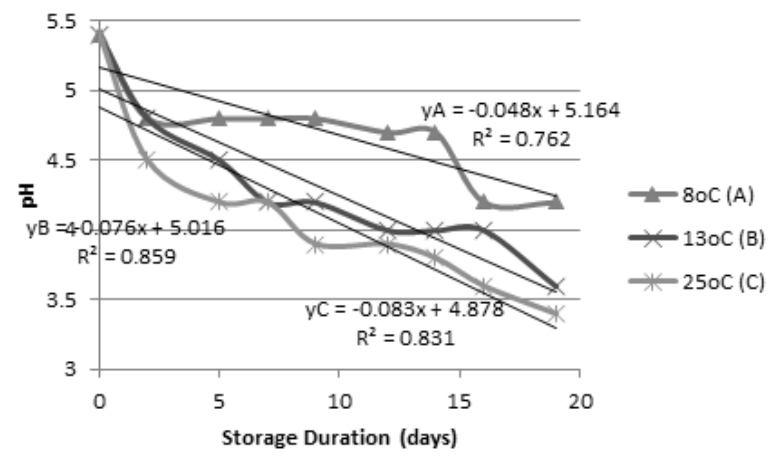

Figure 3. The pH degradation of cold-sterilized coconut water during storage

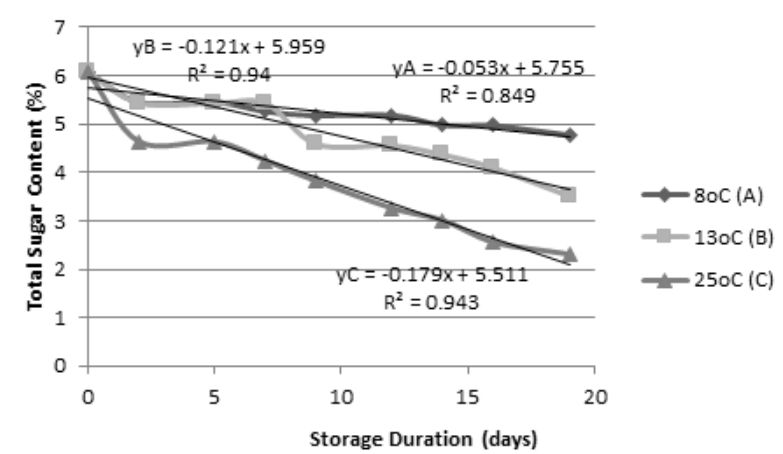

Figure 4. The total sugar content degradation of coldsterilized coconut water during storage

Figure 3 showed that the decrease of $\mathrm{pH}$ was influenced by the higher temperature. The decrease of $\mathrm{pH}$ observed in this research (1.9 points at $8^{\circ} \mathrm{C}$ ) was higher compared to that observed by Awua et. al. (2012) where the $\mathrm{pH}$ of fresh coconut water decreased by 2.3 points after 30 days of storage at $4{ }^{\circ} \mathrm{C}$. The decrease of $\mathrm{pH}$ may occur due to the formation of phenol radicals and phenol oxides, which may also cause the formation of yellowish color of the product (Awua et. al. 2012).

Total sugar content also experienced a declining trend during storage at all temperature, as shown in Figure 4. The decrease od total sugar content may be caused by the utilization of sugar and other simple carbohydrate in the formation of unsoluble matters, which are the essential substance in the coconut endosperm (Awua et. al., 2012).

The quality deterioration of both critical parameters was calculated by determining the slope, intercept and the correlation on reaction order 0 and ordo 1 (Tabel 2 and 3). The determination of reaction order is a means to predict the tendency of quality deterioration (Sukasih et al. 2007). 
Table 2. The value of the slope, intercept, and correlation coefficient in reaction order 0 and 1 and the linear equation of $\mathrm{pH}$ of coconut water drink

\begin{tabular}{llccc}
\hline & & \multicolumn{3}{c}{ Temperature } \\
\cline { 3 - 5 } & & $8^{\circ} \mathrm{C}$ & $13^{\circ} \mathrm{C}$ & $25^{\circ} \mathrm{C}$ \\
\hline Order 0 & R square & 0.76198 & 0.85903 & 0.83134 \\
& Intercept & 5.16466 & 5.01687 & 4.87871 \\
& Slope & -0.04860 & -0.07680 & -0.08340 \\
Order 1 & R square & 0.76663 & 0.88757 & 0.87769 \\
& Intercept & 1.64391 & 1.61509 & 1.58695 \\
& Slope & -0.01030 & -0.01750 & -0.01980 \\
InK (order 1) & & -4.57120 & -4.04780 & -3.92390 \\
T (Kelvin) & & 281 & 286 & 298 \\
1/T (Kelvin) & & 0.00356 & 0.0035 & 0.00336 \\
Linear equation & & \multicolumn{3}{c}{$\mathrm{Y}=-2795.2 \mathrm{X}+5.51908$} \\
& & $\mathrm{R}^{2}=0.71592$ \\
\hline
\end{tabular}

Table 3. The value of the slope, intercept, and correlation coefficient in reaction order 0 and 1 and the linear equation of total sugar content of coconut water drink

\begin{tabular}{llccc}
\hline & & \multicolumn{3}{c}{ Temperature } \\
\cline { 3 - 5 } & & $8^{\circ} \mathrm{C}$ & $13^{\circ} \mathrm{C}$ & $25^{\circ} \mathrm{C}$ \\
\hline Order 0 & R square & 0.84897 & 0.93997 & 0.94359 \\
& Intercept & 5.75566 & 5.95916 & 5.51124 \\
& Slope & -0.05346 & -0.12158 & -0.17954 \\
Order 1 & R square & 0.87119 & 0.93320 & 0.97211 \\
& Intercept & 1.75093 & 1.80140 & 1.74724 \\
& Slope & -0.01003 & -0.02578 & -0.04777 \\
InK (order 1) & & -4.60231 & -2.10721 & -3.04137 \\
T (Kelvin) & & 281 & 286 & 298 \\
1/T (Kelvin) & & 0.00356 & 0.0035 & 0.00336 \\
Linear equation & & \multicolumn{3}{c}{$\mathrm{Y}=-5247.25 \mathrm{X}+14.95929$} \\
& & $\mathrm{R}^{2}=0.18744$ \\
\hline
\end{tabular}

Table 2 and 3 show that the correlation $\left(\mathrm{R}^{2}\right)$ of reaction order 1 is higher than reaction order 0 , for $\mathrm{pH}$ parameter and total sugar content. Lee and Krochta (2002) stated that the quality deterioration reaction of food materials mostly occurs at order 0 and 1 . The kinetic reaction of quality deterioration, oxidative color change, rancidity, microbial growth, and vitamin degradation are the examples of order 1 kinetic reactions. Meanwhile, the order 0 reaction are enzymatic destruction, enzymatic browning, and oxidation.
After the determination of reaction order, shelf-life estimated was calculated using Arrhenius equation. Arrhenius equation obtained by plotting the value of $\ln \mathrm{k}$ with $1 / \mathrm{T}$, where $\mathrm{k}$ was slope value as deterioration value of quality during storage and $\mathrm{T}$ was temperature.

The initial quality values were used in the calculation of shelf-life estimation. The analysis showed that $\mathrm{pH}$ of coconut water sample was 5.4 and the total sugar content was $6.06 \%$. The coconut drink produced in this study was designed to be natural isotonic drink. Therefore the critical limits were determined based on Indonesian National Standard of Isotonic Drink, i.e. 4 for $\mathrm{pH}$ and $5 \%$ for total sugar content.

The Arrhenius equation of the samples in the analysis of parameter $\mathrm{pH}$ was $\mathrm{Ln} \mathrm{K}=\mathrm{LnK}=$ $5.519082-2795.2(1 / \mathrm{T})$, where if it was stored in temperature $8^{\circ} \mathrm{C}$ it would generate the value of $\mathrm{Ln} K=-4.42807$ or $\mathrm{K}=0.01194$. This means that there will be 0.01194 unit decrease of $\mathrm{pH}$ per day. According to the calculation using equation 1 (Sukasih et al. 2007), it was estimated that the shelf-life of coconut water drink were 28 days in $8^{\circ} \mathrm{C}$ storage, 23 days in $13^{\circ} \mathrm{C}$ storage and 15 days in $25^{\circ} \mathrm{C}$ storage (Table 4).

Table 4. The estimation of shelf-life of cold-sterilized coconut water based on $\mathrm{pH}$

\begin{tabular}{lccc}
\hline & \multicolumn{3}{c}{ Temperature } \\
\cline { 2 - 4 } & $8^{\circ} \mathrm{C}$ & $13^{\circ} \mathrm{C}$ & $25^{\circ} \mathrm{C}$ \\
\hline Arrhenius equation & \multicolumn{3}{c}{$\mathrm{LnK}=5.519082-2795.2(1 / \mathrm{T})$} \\
LnK & -4.42807 & -4.25417 & -3.86062 \\
$\mathrm{~K}$ & 0.01194 & 0.0142 & 0.0211 \\
Initial quality (No) & 5.4 & 5.4 & 5.4 \\
Critical limit (Nt) & 4 & 4 & 4 \\
Shelf-life (days) & 28.1862 & 23.6871 & 15.9806 \\
\hline
\end{tabular}

In the analysis of total sugar content, equation Arrhenius Ln K = LnK = 14.95929 $5247.25(1 / \mathrm{T})$, so that storage in $8^{\circ} \mathrm{C}$ will generate the value of $\mathrm{Ln} \mathrm{K}=-3.71421$ or $\mathrm{K}=0.02437$. 
This means that there will be 0.02437 unit decrease of total sugar content per day. Based on the calculation using equation 1 on total sugar content parameter, the estimated shelf-life of coconut water drink were 29 days $\left(8^{\circ} \mathrm{C}\right), 21$ days $\left(13^{\circ} \mathrm{C}\right)$ and 10 days $\left(25^{\circ} \mathrm{C}\right)$ (Table 5).

Table 5. The estimation of shelf-life of cold-sterilized coconut water based on total sugar content

\begin{tabular}{lccc}
\hline & \multicolumn{3}{c}{ Temperature } \\
\cline { 2 - 4 } & $8^{\circ} \mathrm{C}$ & $13^{\circ} \mathrm{C}$ & $25^{\circ} \mathrm{C}$ \\
\hline Arrhenius equation & \multicolumn{3}{c}{ LnK $=14.95929-5247.25(1 / \mathrm{T})$} \\
LnK & -3.71421 & -3.38775 & -2.64894 \\
$\mathrm{~K}$ & 0.02437 & 0.03378 & 0.070726 \\
Initial quality (No) & 6.06 & 6.06 & 6.06 \\
Critical limit (Nt) & 5 & 5 & 5 \\
Shelf-life (days) & 29.6498 & 21.3915 & 10.2184 \\
\hline
\end{tabular}

The calculation of shelf-life estimation may give different results among different critical parameters (Sukasih et al. 2007). The estimated shelf-life using $\mathrm{pH}$ as a critical parameter was different with that of total sugar content. The recommendation of shelf-life should be determined based on the shorter shelf-life, considering the safety of the product (Koswara dan Kusnandar 2004), or based on the higher correlation value (Sukasih et al. 2007).

According to the aforementioned considerations, it was determined that the calculation of shelf-life estimation using $\mathrm{pH}$ was to be used. When stored in the room temperature $\left(25^{\circ} \mathrm{C}\right)$, the shelf-life of coconut water drink is 15 days. This result is shorter compared to the results in Kailaku et al. (2006) and Naozuka (2004). Kailaku et al. (2006) studied the shelf-life of coconut water drink produced using ultrafiltration membrane and showed that the product was still in good quality after 3 months storage in the refrigerator. However, the product was formulated with the addition of food additives such as sodium carbonate and citric acid, which acted as preservative and acidity controller agents. Naozuka (2004) conducted research using the freezing method, resulted in the shelf-life of coconut water of 30 days. Unfortunately, there were physicochemical, and enzymatic degradation observed after the thawing process.

The Total Plate Count analysis of the product showed the total microbes of $1.08 \times 10^{1} \mathrm{CFU} / \mathrm{ml}$, while fresh coconut water contained $1.86 \times 10^{2}$ $\mathrm{CFU} / \mathrm{ml}$ total microbes. The Indonesian $\mathrm{Na}$ tional Standard required the maximum total microbes of $2 \times 10^{2} \mathrm{CFU} / \mathrm{ml}$. Unprocessed coconut water had more than $10^{10} \mathrm{CFU} / \mathrm{ml}$ total microbes after 19 days storage at any temperature. Meanwhile, the total microbes of cold-sterilized coconut water were $1.94 \times 10^{2} \mathrm{CFU} / \mathrm{ml}\left(8^{\circ} \mathrm{C}\right)$, $2.50 \times 10^{2} \mathrm{CFU} / \mathrm{ml}\left(13^{\circ} \mathrm{C}\right)$ and $4.70 \times 10^{2} \mathrm{CFU} / \mathrm{ml}$ $\left(25^{\circ} \mathrm{C}\right)$ after 19 days storage. This result should be further studied in order to identify the type of growing microbes. Not only to study if there were undesired microbes grows, e.g., E. coli, but also to confirm the possibility of using the $\mathrm{pH}$ and nutritional composition of coconut water as a medium of useful bacteria such as Acetobacter xylinum and Lactobacillus sp.

Although the shelf-life obtained in this study was fairly long compared to that of unprocessed coconut water, this result is not enough for an industrial purpose such as distribution and transportation, which need more extended shelf-life. However, scaled up production is expected to have a better result, considering various weak aspects that may interfere the quality assurance of laboratory scale in this study, e.g., the less than optimum processing condition of ultrafiltration membrane and the non-fully aseptic processing condition. Production and distribution using cold chain system are expected to have a far better result.

Moreover, Prades et al. (2012) reviewed nu- 
merous research reports on the processing and the shelf-life of coconut water and concluded that thermal treatments i.e. pasteurization, sterilization, and non-thermal treatments i.e. microfiltration were not enough to obtain an extended shelf-life of coconut water without the addition of any food additives. An effective result may be obtained by adding molecules e.g., nisin, ascorbic acid, citric acid, and sodium metabisulfite. Studies using those materials succeeded in maintaining the quality of pasteurized coconut water for $2-3$ months at room temperature or refrigerator.

\section{CONCLUSIONS}

Cold-sterilized coconut water obtained from processing using ultrafiltration membrane and ultraviolet, without the addition of food additives experienced the decrease of $\mathrm{pH}$ and total sugar content during storage. The estimation of shelf-life using Accelerated Storage Study with Arrhenius equation, based on $\mathrm{pH}$ as critical parameter showed that the product's shelf-life was 15 days at $25^{\circ} \mathrm{C}$. This result was better than the shelf-life of unprocessed coconut water, but not adequate for industrial scale and distribution purpose.

\section{REFERENCES}

Ahrne L.M, Manso M.C, Shah E, Oliveira FAR and Oste RE. 1996. Shelf-life prediction of aseptically packaged orange juice. [Abstract]. Chemical Markers for Processed and Stored Foods, 631:107-17.

American Public Health Association (APHA). 1998. Standard Methods For The Examination of Water and Waste Water. 20th edition. Di dalam Roji F. 2006. Pembuatan produk minuman isotonik (isotonic drink) dalam kemasan gelas plastik di PT. Fits Mandiri Bogor. Skripsi. Fakultas Teknologi Pertanian. IPB.

Awua AK, Doe ED, and Agyare R. 2012. Potential bacterial health risk posed to consumers of fresh coconut water. Food and Nutrition. 3:1136:1143.

Duarte ACP, Coelho AAZ, and Leite SGF. 2002. Identification of peroxidase and tyrosinase in green coconut water. Ciencia y Tecnologı́a Alimentarı'a, 3(5), 266-270.
Falguera V, Pagan J, Garza S, Garvin A, and Ibarz A. 2011. Ultraviolet processing of liquid food: A review. Part 2: Effects on microorganisms and on food components and properties. Food Res Intl. 44(2011): 1580-1588.

Food and Agriculture Organization (FAO). 2000. Press release: Coconut water as energy drink for joggers and athletes First patent granted to UN Food Agency. http://www.fao. org/default.htm. Diakses 5 Maret 2014.

Haynes K, Bundang R, Chu 0, Eichinger C, Lineback DS, and Bolles AD. 2004. Method for production of coconut water beverage and blended juice beverages with coconut water. US Patent. US 2004/0018285 A1.

Hidayati N. 1992. Penentuan tiamin, riboflavin dan piridoksin dalam beras dengan HPLC secara serentak. Pusat Aplikasi Isotop dan Radiasi, Badan Tenaga Nuklir Nasional. http:// digilib.batan.go.id/e-prosiding/File Prosiding/ Pertanian_Peternakan /Hasil_Penelitian_1990-1992_PAIR/ Data_Artikel/ Nurhidayati-111.pdf Diakses 21 November 2014

Hough G, Garitta L and Gomez G. 2006. Sensory shelf life predictions by survival analysis accelerated storage models. [Abstract]. Food Quality and Preference, 17(6):468-473.

Kailaku SI, Dewandari KT dan Syah ANA. 2006. Perbaikan mutu minuman isotonik alami air kelapa dengan teknologi ultrafiltrasi. Prosiding Lokakarya Nasional: Strategi Peningkatan Nilai Tambah Hasil Pertanian melalui Penerapan Teknologi Pascapanen dan Sistem Keamanan Pangan. Balai Besar Litbang Pascapanen Pertanian, 12 September 2006.

Kailaku, Sl., B Setiawan and A Sulaeman. 2016. Pengaruh Proses Membran Ultrafiltrasi dan Ultraviolet terhadap Komposisi Gizi, Sifat Fisikokimia dan Organoleptik Minuman Air Kelapa. Jurnal Littri Vol. 22 No. 2.

Koswara S dan Kusnandar F. 2004. Studi kasus pendugaan umur simpan produk pangan. Pelatihan Pendugaan Waktu Kadaluarsa Bahan dan Produk Pangan. Di dalam Sukasih E, Sunarmani dan Budiyanto A. 2007. Pendugaan umur simpan pasta tomat kental dalam kemasan botol plastik dengan metode akselerasi. J Pascapanen, 4(2):72-82.

Lee SY and Krochta JM. 2002. Accelerated shelf life testing of whey protein coated peanuts analyzed by static headspace Gas Chromatography. [Abstract]. J Agric Food Chem, 50:2022-2028.

Magalhaes MP, Gomes FS, Modesta RCD, Matta VM and Cabral LMC. 2005. Conservation of green coconut water by membrane filtration. Ciencia y Tecnología Alimentarı́a, 25(1):72-77.

Maria GC and Peleg M. 2007. Shelf-life estimation from accelerated storage data. [Abstract]. Trend in Food Science and Technology, 18:37-47.

Nakano LA, Leal WF Jr, Freitasb DGC, Cabralb LMC, Penhab EM, Penteadob AL and Mattab VM. 2011. Coconut water processing using ultrafiltration and pasteurization. Proceeding of International Congress on Engineering and Food, 11, 2011, Athens. National Technical University of Athens.

Naozuka J. 2004. Estudo da influencia de processos de conservacao na distribuicao de species elementares em agua de coco por espectrometria de absorcao e emissao atomic. Master thesis. [Abstract]. Instituto de Quimicha, Brazil. 
Prades A, Dornier M, Diop N, and Pain JP. 2012. Coconut water preservation and processing: a review. Fruits 2012, 67, 157-171.

Sukasih E, Sunarmani dan Budiyanto A. 2007. Pendugaan umur simpan pasta tomat kental dalam kemasan botol plastik dengan metode akselerasi. J Pascapanen, 4(2):72-82.

Sulaeman A, Anwar F, Rimbawan, dan Marliyati SA. 1995. Metode analisis zat gizi dan komponen kimia lainnya dalam makanan. Di dalam Riyana R. 2008. Mutu dan daya simpan air kelapa (Cocos nucifera $L$.) yang berpotensi sebagai minuman isotonik [skripsi]. Fakultas Pertanian. Institut Pertanian Bogor. 